\title{
Pengaruh Perlakuan Pendahuluan Terhadap Sifat Kimia Tepung Umbi Suweg Yang Dihasilkan
}

\author{
Indriyani, Ika Gusriani, Mursyd \\ Jurusan Teknologi Pertanian, Universitas Jambi, Indonesia \\ E-mail: indriyani@unja.ac.id
}

\begin{abstract}
ABSTRAK
Suweg merupakan salah satu jenis tanaman umbi-umbian yang banyak menghasilkan karbohidrat. Kandungan karbohidrat yang tinggi pada umbi suweg memungkinkan umbi suweg bisa digunakan sebagai pengganti tepung terigu.Permasalahannya adalah dihasilkan tepung umbi suweg yang berwarna kurang cerah.Tujuan penelitian ini adalah untuk mengetahui pengaruh berbagai macam perlakuan pendahuluan terhadap sifat kimia tepung umbi suweg yang dihasilkan. Penelitian ini menggunakan Rancangan Acak Lengkap yang terdiri dari 5 perlakuan yaitu : P0 : Tanpa perlakuan, P2 : Penambahan asam askorbat 4\%, P3 : Penambahan Natrium Metabisulfit 2500 ppm, P4 : Hot water Blanching suhu 100 selama 5 menit dan P5 : Steam blanching selama 5 menit.. Hasil penelitian menunjukkan bahwa perlakuan pendahuluan tidak berpengaruh terhadap daya serap air, daya serap minyak dan kadar asam oksalat tapi berpengaruh nyata terhadap protein
\end{abstract}

Kata kunci : Suweg,blanching, steam,tepung

\section{PENDAHULUAN}

Suweg (amorphophallus campanulatus) merupakan salah satu tanaman yang masih tumbuh liar di Indonesia yang belum banyak dibudidayakan. Diawal dan akhir musim kemarau tanaman ini untuk tumbuh dan bertunas (Kasno, dkk 2009 dalam Umar dan Rini, 2017). Umbi suweg adalah salah satu sumber karbohidrat yang berpotensi sebagai tepung maupun pati (Richana dan sunarti, 2004). Umbi suweg memiliki kadar pati sebesar 83,86\% dengan rasio kadar amilosa: amilopektin sebesar 24,1\%: 58,95\% (Pramesti, dkk., 2015). Komposisi gizi kimia tepung suweg dalam 100 gram adalah karbohidrat 83,18 gram, protein 7,20 gram, 0,28 gram, 4,60 gram, 4,74 gram (Faridah, 2005).Komposisi lainnya dalam tepung suweg adalah kalsium oksalat dan asam oksalat. Kalsium oksalat dapat dihilangan dengan perendaman dalam larutan garam dan diolah menjadi tepung. Asam oksalat pada umbi suweg segar bernilai 0,01 sampai 0,08\% sedangkan tepung suweg berkisar 0.11- 0,21\% (Yuzammi dan Handayani, 2019). 
Penanganan pasca panen umbi suweg yaitu dengan diolah menjadi tepung sehingga lebih tahan lama disimpan dibandingkan disimpan dalam bentuk umbi. Penelitian Faridah (2005) menghasilkan tepung suweg yang memiliki warna krem disebabkan oleh terjadinya reaksi pencoklatan pada saat pengupasan umbi sehingga chips yang dihasilkan tidak berwarna cerah. Reaksi pencoklatan dapat dihambat dengan beberapa proses pengolah yaitu dengan perendaman air atau blanching, uap panas serta bleaching menggunakan senyawa kimia antara lain asam askorbat dan natrium metabisulfit.

Menurut Syamsiah (2011), bahwa dalam mengurangi atau meminimalkan kandungan kalsium oksalat pada umbi tire (suweg) yaitu pengolahan dengan cara perebusan dapat menurunkan kalsium oksalat sebesar 0,008 \% menjadi $0.050 \%$ dengan kadar kalsium oksalat suweg segar sebesar $0.058 \%$.

Penelitian ini bertujuan untuk menghasilkan tepung suweg yang berwarna lebih cerah dengan memberikan perlakuan pada umbi suweg untuk dijadikan tepung berbagai macam perlakuan pendahuluan.

\section{METODOLOGI PENELITIAN}

\section{Bahan dan Alat}

Bahan utama yang digunakan dalam pembuatan tepung yaitu umbi suweg dari desa Sungai Terap, Kumpeh Ulu, Kab. Muaro Jambi, asam askorbat 4\%, Natrium Metabisulfit 2500 ppm, akuades. Bahan yang digunakan untuk analisa tepung adalah akuades, minyak jagung, katalis campuran, $\mathrm{H} 2 \mathrm{SO} 4$ pekat, $\mathrm{H} 2 \mathrm{SO} 4$ 0,3 N, indikator campuran, $\mathrm{NaOH} 40 \%$, dan $\mathrm{NaOH}$ 0,3 N.

Alat-alat yang digunakan dalam pembuatan tepung suweg adalah pisau, talenan, baskom, oven, loyang, blender, alumunium foil, timbangan digital, ayakan 60 mesh, dan plastik ziplok,. Alat yang digunakan untuk analisa adalah colour reader, oven, desikator, cawan, $\mathrm{pH}$ meter, gelas kimia $25 \mathrm{~mL}$, batang pengaduk, vortex, sentrifuse, tabung sentrifuse, tisu, labu dekstruksi, labu destilasi, destilator, pemanas listrik, labu erlenmeyer $250 \mathrm{~mL}$ dan $500 \mathrm{~mL}$, biuret, corong, pipet, gelas ukur, neraca analitik, dan batu didih.

\section{Pelaksanaan Penelitian}

Penelitian dilaksanakan menggunakan Rancangan Acak Lengkap (RAL) dengan 5 perlakuan yaitu kontrol, penambahan asam askorbat $4 \%$, Natrium metabisulfit 2500 ppm, hot water blanching, steam blanching selama 5 menit. Setiap perlakuan diulang 3 kali sehingga didapat 15 satuan percobaan.

\section{Pembuatan tepung suweg}

Proses pembuatan tepung suweg dilakukan dengan cara sortasi umbi suweg yang akan digunakan, kemudian dibersihkan dari tanah yang ada dipermukaan kulit. Selanjutnya umbi suweg dikupas menggunakan pisau dan dicuci dengan air bersih. 
Setelah itu, ditimbang 800 gram umbi suweg, lalu dipotong menjadi 4 bagian dan diiris menggunakan slicer dengan ketebalan $\pm 1-2 \mathrm{~mm}$. Pembuatan tepung dilakukan dengan 5 perlakuan yaitu perendaman asam askorbat 4\%, Natrium metabisulfit 2500 ppm direndam selama 120 menit, hot water blanching, steam blanching selama 5 menit serta kontrol atau tanpa perlakuan langsung ditiriskan dan dikeringkan dalam oven pengering dengan suhu $70{ }^{\circ} \mathrm{C}$ selama $6-7$ jam sedangkan untuk yang direndam asam askorbat dan natrium metabisulfit selama \pm 12 jam.

\section{Parameter yang diamati}

Parameter yang diamati pada penelitian ini adalah Daya serap air, daya serap minyak (Falade dan Cristoper,2015), Protein (AOAC, 1980) dan Asam oksalat (Ukpabi dan Edijoh, 1980) .

\section{Analisa Data}

Data yang diperoleh dianalisa ragam pada taraf $1 \%$ dan $5 \%$ apabila berbeda nyata dilanjutkandengan uji DNMRT pada taraf 5\%.

\section{HASIL DAN PEMBAHASAN}

\section{Daya Serap Air}

Daya serap air atau kapasitas penyerapan air yaitu merupakan kemampuan tepung dalam menyerap air dengan cara disentrifuge, serta menentukan jumlah air yang tersedia untuk proses gelatinisasi pati selama pemasakan (Handiskawati, 2012). Hasil sidik ragam menunjukkan perlakuan dengan berbagai macam metode tidak berpengaruh nyata terhadap daya serap air. Berdasarkan diagram, dapat dilihat bahwa perlakuan dengan perendaman natrium metabisulfit menghasilkan nilai paling tinggi dengan nilai 2,17. Hal ini disebabkan oleh natrium metabisulfit yang bersifat merusak dinding sel jaringan bahan sehingga absorpsi air oleh bahan menjadi lebih tinggi (Rahman dan Perera, 1999). Daya serap tersebut dapat dilihat pada Gambar 1.

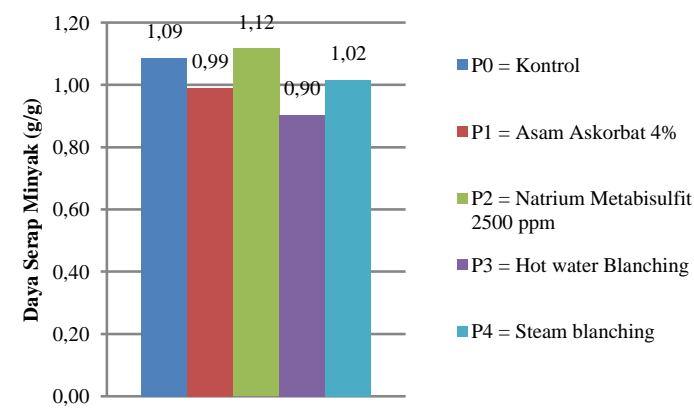

Gambar 1. Grafik rata-rata daya serap air tepung suweg pada berbagai macam perlakuan 


\section{Daya Serap Minyak}

Kapasitas penyerapan minyak dipengaruhi kadar protein dan lemak, seperti yang dinyatakan Aini dkk. (2010) bahwa semakin besar kadar lemak atau protein, semakin besar kapasitas penyerapan minyak. Hal ini berhubungan dengan mekanisme kapasitas penyerapan minyak yang disebabkan pemerangkapan minyak secara fisik dengan gaya kapiler dan peran hidrofobisitas protein. Hal ini juga sesuai dengan Sirivongpaisal (2008) yang menyatakan bahwa kapasitas penyerapan minyak pada tepung bambara groundnut lebih besar daripada pati bambaragroundnut karena kadar protein dan lemak yang lebih tinggi pada tepung, yang dapat memerangkap lebih banyak minyak. Grafik rata-rata daya serap minyak tepung suweg pada berbagai macam perlakuan dapat dilihat pada Gambar 2.

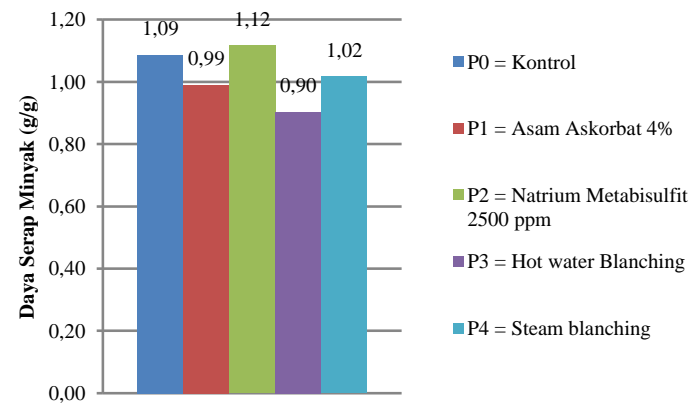

Gambar 2. Grafik rata-rata daya serap minyak tepung suweg pada berbagai macam perlakuan

Penyerapan minyak selain terjadi karena minyak terperangkap secara fisik dalam protein tetapi juga terdapatnya ikatan non kovalen seperti atraksi hidrofobik, eletrostastik dan ikatan hidrogen padainteraksi lemak protein (Lawal, 2004). Protein sangat berpengaruh terhadap kenaikan daya serap minyak. Daya serap minyak tersebut dapat dilihat pada Gambar 2.

\section{Protein}

Perlakuan blanching steam dan hotwater memperlihatkan kadar protein yang lebih rendah akibat pada suhu tersebut protein mengalami denaturasi sehingga protein yang terdeteksi pada tepung suweg menjadi rendah. Hal ini sesuai dengan Jhon M. (1999) yang menyatakan protein berdenaturasi pada kisaran suhu antara 55-75oC, dengan ditemukan efeknya pada tekstur, kapasitas penyimpanan air dan penyusutun umur simpan. Grafik rata- rata protein tepung suweg pada berbagai macam perlakuan pada Gambar 3. 


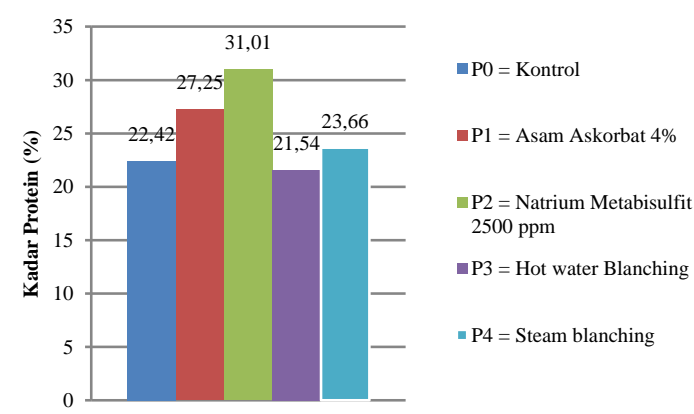

Gambar 3 . Grafik rata-rata protein tepung suweg pada berbagai macam perlakuan

\section{Asam Oksalat}

Asam oksalat adalah senyawa kimia yang memiliki nama sistematis asam etanadionat. Asam oksalat dapat ditemukan dalam bentuk bebas ataupun dalam bentuk garam. Bentuk yang lebih banyak ditemukan adalah bentuk garam (Noonan dan Savage, 1999). Hasil sidik ragam menunjukkan perlakuan dengan berbagai macam metode tidak berpengaruh nyata terhadap Kadar Asam Oksalat. Metode rebus atau Hot water blanching memberikan nilai terkecil terhadap penurunan oksalat yaitu sebesar $48.60 \mathrm{mg} / 100 \mathrm{~g}$. Menurut Rosman et al., (1994) dalam Purwanto (2013) menyatakan bahwa dari 100g umbi suweg (Amorphophallus campanulatus) mengandung kristal asam oksalat sebanyak 382 mg. Penurunan kadar oksalat karena perebusan terkait dengan kelarutan oksalat yang meningkat pada suhu tinggi. Perebusan juga menyebabkan kerusakan pada kulit umbi talas dan memudahkan keluarnya oksalat terlarut dari dalam umbi ke dalam air perebus (Albihin dan Savage, 2001). Grafik rata- rataasam oksalat tepung suweg pada berbagai macam perlakuan pada Gambar 4.

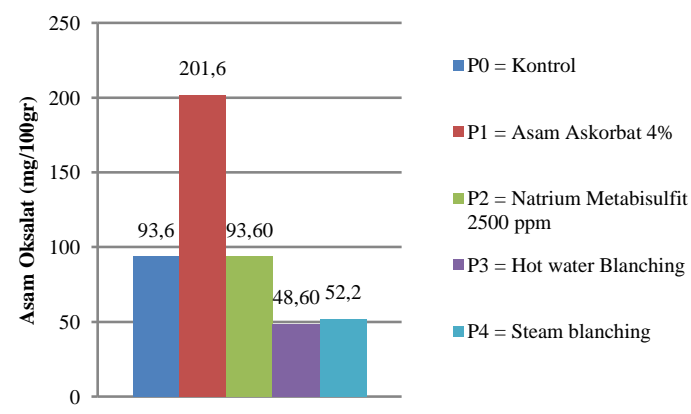

Gambar 4. Grafik rata-rata asam oksalat tepung suweg pada berbagai macam perlakuan 


\section{KESIMPULAN DAN SARAN}

Berdasarkan hasil penelitian yang telah dilakukan maka dapat disimpulkan sebagai berikut:

1. Perlakuan pendahuluan berpengaruh terhadap protein tepung suweg yang dihasilkan dan tidak berpengaruh terhadap daya serap air,daya serap minyak dan kadar asam oksalat.

2. Perlakuan Natrium metabisulfit memberikan hasil yang tertinggi terhadap kadar protein tepung umbi suweg yang dihasilkan

Disarankan pada pembuatan tepung umbi suweg menggunakan Natrium Metabisulfit 2500 ppm

\section{UCAPAN TERIMA KASIH}

Terima kasih diucapkan kepada Fakultas Pertanian dan Lembaga Penelitian dan Pengabdian Kepada Masyarakat Universitas Jambi yang telah mendanai penelitian ini melalui Proyek Penelitian Terapan Unggulan Universitas Tahun 2020

\section{DAFTAR PUSTAKA}

Aini, N., Hariyadi, P., Muchtadi, T. R., \& Andarwulan, N. (2010). Hubungan antara waktu fermentasi grits jagung putih dengan sifat gelatinisasi tepung jagung putih yang dipengaruhi ukuran partikel. Jurnal Teknologi dan Industri Pertanian, 21(1), 18-24.

Albihin, P, B, E., Savage, G. P. 2001. The Effect of Cooking on the Location and Concentration of Oxalatein Three Cultivars of New Zealand- grown Oca (Oxalls Tuberose Mol). Journal of the Science of Food and Agriculture81. 10271033.

Cocoyams (Xanthosoma and Colocasia spp). Technical Paper presented at the 5th Annual Conferenceof theAgricultural Society of Nigeria, Federal University of Technology, Owerri, Nigeria, 3-6 Sept.

Falade, K. O., dan Christopher, A. S. (2015). Physical, functional, pasting danthermal properties of flours dan starches of six Nigerian Rice cultivars.Food Hydrocoloids, 44, 478-490

Faridah, Didah Nur. 2005. Sifat Fisikokimia Tepung Suweg (Amorphophallus campanulatus BI) dan Indeks Glikemiknya. Jurnal Teknologi dan Industri Pangan. Vol. 16. No.3.

Handiskawati. 2012. Artikel Ilmiah Pengaruh Perbandingan Tepung Terigu dengan Tepung Bonggol Pisang (Musa Paradisiaca) terhadap daya serap Airdan Daya Terima Brownies. Universitas Muhammadiyah Surakarta: Surakarta.

Jhon, M. 1999. Principles of Food Chemistry Third edition. Department of Food Science,University of Guelph, Ontario. 366-372. 
Lawal, O. S. 2004. Composition, physicochemical properties and retrogradation characteristics of native, oxidized, acetylated and acid-thinned new cocoyam (Xanthosoma sagittifolium) starch. Food Chemistry 87:205- 218.

Noonan,S and Savage,G. P. 1999. Oxalate content of Food and Human Asia Fasific Journal of Clinical Nutrition.8 (1): 64-67.

Pramesti, H. A, Kusoro, S, dan Edy, C. 2015. Analisis Rasio Kadar Amilosa Atau Amilopektin dalam Amilum dari beberapa Jenis Umbi. Jurnal Ilmu Kimia Indonesia. Vol. 4. No. 1.

Purwanto, C.,C., Ishartani, D., dan Rahadian, D. 2013. Kajian Sifat Fisik dan Kimia Tepung Labu Kuning (Cucurbita maxima) dengan Perlakuan Blanching dan Perendaman Natrium Metabisulfit. Jurnal Teknosains Pangan. Vol.2. No.2.

Rahman, M.S., dan Perera, C.O. 1999. Heat Pump Dehumidifier Drying of Food. Trends Atmosphere. International Journak of Food Properties 1(3): 197- 205.

Richana, Nur dan Tuti Chandra Sunarti. 2004. Karakteristik Sifat Fisikokimia Tepung Umbi dan Tepung Pati dari Umbi Ganyong, Suweg, Ubi Kelapa, dan Gembili. Jurnal Pascapanen Vol. 1. No.1.

Sirivongpaisal, P. 2008. Structure and Fuctional Properties of Starch and Flour From Bambarra Groundnut. Songklanakarin Journal of Science and Technology 30 (Suppl.1), 51-56.

Sudarmadji, S, Bambang, H dan Suhardi. 1997. Prosedur Analisa untuk Bahan Makanan dan Pertanian. Liberty: Yogyakarta.

Syamsiah. 2011. Pengaruh Cara Pengolahan Umbi Tire (Amorphophallus sp.) terhadap Kadar Kalsium Oksalat. Jurnal Bionature Vol. 12. No.2.

Ukpabi, U. J. \& Ejidoh, J. I. 1989. Effect of Deep Oil Frying on the Oxalate Content and the Degree of Itching of

Umar, Hafidz, A, H dan Rini,U. 2017. Perbedaan Sifat Fisik, Kimia dan Sensori Tepung Umbi Suweg (Amorphophallus Campanulatus BI) pada Fase Dorman dan Vegetatif. Jurnal Agrosains. Vol. 5. No.2.

Yuzammi dan Handayani, T. 2019. Analysis of Nutrient and Anti-Nutrient Compositions of Suweg Cultivated in Java. Research Center for Plant Conservation and Botanic Gardens - Indonesian Institute of Sciences. 